\title{
Chapter 15 \\ Long-term Development and Current Socio-Spatial Differentiation of Housing Estates in Prague, Czechia
}

\author{
Martin Ouředníček, Petra Špačková and Lucie Pospíšilová
}

\begin{abstract}
The housing estate is perceived to be one of the main symbols of the socialist regime in the former Eastern Bloc. Immediately after the Velvet Revolution, housing estates were to some extent rejected by the general public as well as neglected in spatial planning and policies. At the same time, Prague's housing estates contained more than $40 \%$ of the city's population, thus representing the most important part of the built environment within the city. The main aims of this chapter are to evaluate the specific development of Prague's housing estates in the second half of the twentieth century, and then to explore the finer details of their inherent socio-spatial differentiation. The role of state and local housing policy is evaluated as the crucial factor in the current and future development of housing estates. The results are similar to those for many other CEE cities, and confirm that the transformation period had little impact on social structures within these residential areas and that the social mix sustains the main attribute of Prague's housing estates. New housing construction and ethnic differentiation are the most important processes to have changed the social environment of housing estates in Prague during the post-transformation period.
\end{abstract}

Keywords Housing estates · Housing policy • Socio-spatial differentiation Prague

M. Ouředníček $(\bowtie) \cdot$ P. Špačková · L. Pospíšilová

Faculty of Science, Department of Social Geography and Regional Development,

Charles University, Prague, Czechia

e-mail: martin.ourednicek@natur.cuni.cz

P. Špačková

e-mail: petra.spackova@natur.cuni.cz

L. Pospíšilová

e-mail: lucie.pospisilova@natur.cuni.cz

(C) The Author(s) 2018

D. B. Hess et al. (eds.), Housing Estates in Europe, The Urban Book Series,

https://doi.org/10.1007/978-3-319-92813-5_15 


\subsection{Introduction}

Housing estates (sídliště) represent an integral part of the physical and social environment in cities, towns and even small villages within the whole of Czechia. Behind the single term-sídliště-various structures are hidden. Czech housing estates comprise huge settlements of panel apartment houses that constitute a considerable part of the urban housing stock on the one hand, and solitary houses on the peripheries of small villages (bytovka) on the other. Like the sickle and hammer, the red stars, and the communist slogans on the streets, housing estates are icons of the socialist era. The symbols of the previous era may have disappeared from public space almost immediately after the revolution, but housing estates are still one of the most prominent structures in Czech cities (Novotná 2010). Today, they comprise approximately one-third of the housing stock in Czechia and more than $40 \%$ of that in Prague.

The size of this proportion is itself sufficient to legitimise the social and scientific relevance of the research on housing estates. However, since sociologist Jiří Musil and his colleagues wrote the famous Lidé a sídliště (People and Housing Estates) in 1985, no similar focused work has been published in Czechia ${ }^{1}$ and only a few authors have subjected the question of housing estates in Prague to international debate (Temelová et al. 2011; Temelová and Slezáková 2014; Ouředníček 2016). Others published only in the Czech language (e.g. Maier 2003; Barvíková 2010; Špaček 2012), focus on the development of the whole of Prague, where housing estates are only part of the discourse (Špačková et al. 2016), or evaluate only selected Prague housing estates as a part of a broader analysis covering the whole of Czechia (Špačková and Pospíšilová 2017).

With this in mind, the main aim of this chapter is to evaluate and explain the development of Prague's housing estates in the second half of the twentieth and the beginning of the twenty-first centuries. Specifically, we intend to discuss the impact of changing state and city policies on the social structure of residents of housing estates, and its spatial differentiation. To this end, three periods of housing estate development are evaluated in the text. The first part relates to the description and explanation of state and local policies enacted in Czechoslovakia over the period 1948-1993, which saw the construction of housing estates in Prague and the development of the socio-spatial differentiation of housing estates, using the data from population censuses on location, size, tenure structure and population. The period after the Velvet Revolution (after 1989) is divided into two parts, namely, transformational and contemporary development, in which we again discuss specific policies and strategies, and the development of socio-spatial differentiation in housing estates in Prague.

\footnotetext{
${ }^{1}$ Several recently published works focus mainly on architecture and urbanism in selected housing estates (e.g. Zarecor 2011; Zadražilová 2013; Skřivánková et al. 2017).
} 


\subsection{History of Housing Estates in Prague}

Although the main ideas behind housing estates were developed well before World War II (Zadražilová 2013), the history of large housing estates in Czechoslovakia is strongly tied to the post-war period and the ideology of the Communist Party. For the delimitation of the subject of study, we refer to 'socialist housing estates', keeping in mind certain limitations of this term. Prague's first post-war (pre-socialist) housing estate, Solidarita, was built in 1947-1949, based on the regulatory plan of 1938. Several houses of the most recent generation (e.g. Černý Most II) were finished in 1993, 4 years after the Velvet Revolution. However, the vast majority of estates originate from the socialist period.

The general development of housing construction in Czechoslovakia was determined by national strategies; among them industrialisation and urbanisation strategies. These strategies led to heavy investment in industrial centres, and from the 1960s, the creation of the Central Settlement System (středisková soustava osidleni) supporting selected centres of newly established administrative districts (76 districts-okres). Planning at the national level was based on a combination of specific housing policy and a marked shortage of flats (Hampl and Kühnl 1993). Unlike many other cities, Prague sustained only slight damage during the war years. Early post-war housing construction was focused more on the restoration of damaged housing stock and construction on prepared plots, rather than on new larger projects (Borovička and Hrůza 1983). A major turning point in the development of Prague was the communist coup in February 1948. The relatively favourable housing situation compared to other cities in Czechoslovakia, supported by the migration of Prague residents to border regions from which the Germans had been expelled, together with the release of houses occupied by the Germans during the war, caused a shift of investment from housing to industry and to industrial cities other than Prague during the post-war period (Kohout and Vančura 1986; Matějů 1977).

The Communist Party soon began to promote specific policies reflecting efforts to reduce social disparities. Attempts were made to reduce differences in society via several measures such as the nationalisation of most apartment houses, rent regulation, the division of large housing units into several smaller ones and the abolition of the land market and the introduction of regulated or fixed land prices (Musil 2005a). The main objective was to improve conditions for working-class families in overcrowded apartments (Votrubec 1965); later, the aim was to solve the housing shortage (Matějů et al. 1979). Socialist housing construction was oriented towards homogenisation and elimination of differences either between regions within Czechoslovakia (in particular, between the Czech and Slovak parts of the Republic) or even between neighbourhoods within cities (Steinführer 2003). State and cooperative housing construction were financially supported and rationing of apartments was introduced. Initial redistribution of apartments aimed at the elimination of class inequality that took place within the existing housing stock, which then stagnated until the early 1960s (Matějů 1980). 
During the 1950s and 1960s, the socialist regime succeeded, through restrictions on housing construction, in controlling residential mobility, and at least to some extent, population growth in Prague (Matějů et al. 1979; Musil 2006). The real housing crisis came soon afterwards, primarily as a result of higher fertility rates and growing immigration to Prague (Matějů et al. 1979), but also as a consequence of the restrictive policies described herein. However, the construction of housing estates, which grew in the mid-1960s and was in full swing during the 1970s and 1980s, brought with it new dynamics in terms of population development (Matěju 1977; Matějů et al. 1979). This construction significantly changed the physical and social fabric of the city (Musil 2005b).

As early as the 1950s, a tendency towards standardisation and industrialisation appeared in housing construction, and the first prefabricated houses were built in Prague during the 1960s. This type of construction became dominant in new housing during the socialist period (Borovička and Hrůza 1983). The policy of Comprehensive Housing Construction (komplexní bytová výstavba) represented a planning tool to manage the construction of housing estates centrally at the national level. The aim of the policy was to enhance the integrity of the process of both project planning and construction (Zadražilová 2013). New industrial methods of housing construction, prefabrication and standardisation were introduced. The outcome of the socialist housing construction was a comprehensive housing estate providing residential buildings and civic amenities, whose scope was determined using so-called technical-economic indicators. This followed the Soviet concept of residential areas as smaller organisational units (Zadražilová 2013). The implementation of the policy of Comprehensive Housing Construction brought changes at the institutional level and led to the concentration of planning and construction in large-state institutions_-project institutes (projektové ústavy) and large construction companies.

During the years 1961-1970, a 16\% increase in the number of dwelling units was recorded in Prague, which was significantly lower than it was in the other main cities of Czechoslovakia (Borovička and Hrüza 1983). The attention of the government and Communist Party then turned to Prague during the 1970s because it lagged behind other socialist capitals due to a lack of investment (Kohout and Vančura 1986). The government approved plans for extensive construction of housing estates on the outskirts of the city and the most extensive housing construction in Prague took place during the 1970s. Newly designed residential units exceeded the administrative borders of the city, which was partly the reason for the expansion (Hrůza 1989). The city's development was also made possible due to the construction of the subway (metro) with the first line coming into operation in 1974 (Fig. 15.1).

Two concentric rings of housing estates rose up around the city centre (Fig. 15.1 and Table 15.1). Older housing estates from the 1950s and 1960s were often connected to the city centre by tramways (Fig. 15.2). The newer estates were built as greenfield developments and were much larger than similar projects in capitalist cities (Musil 2005b; Temelová et al. 2011). The construction of so-called 'new towns' created three large complexes of relatively autonomous settlements: North 


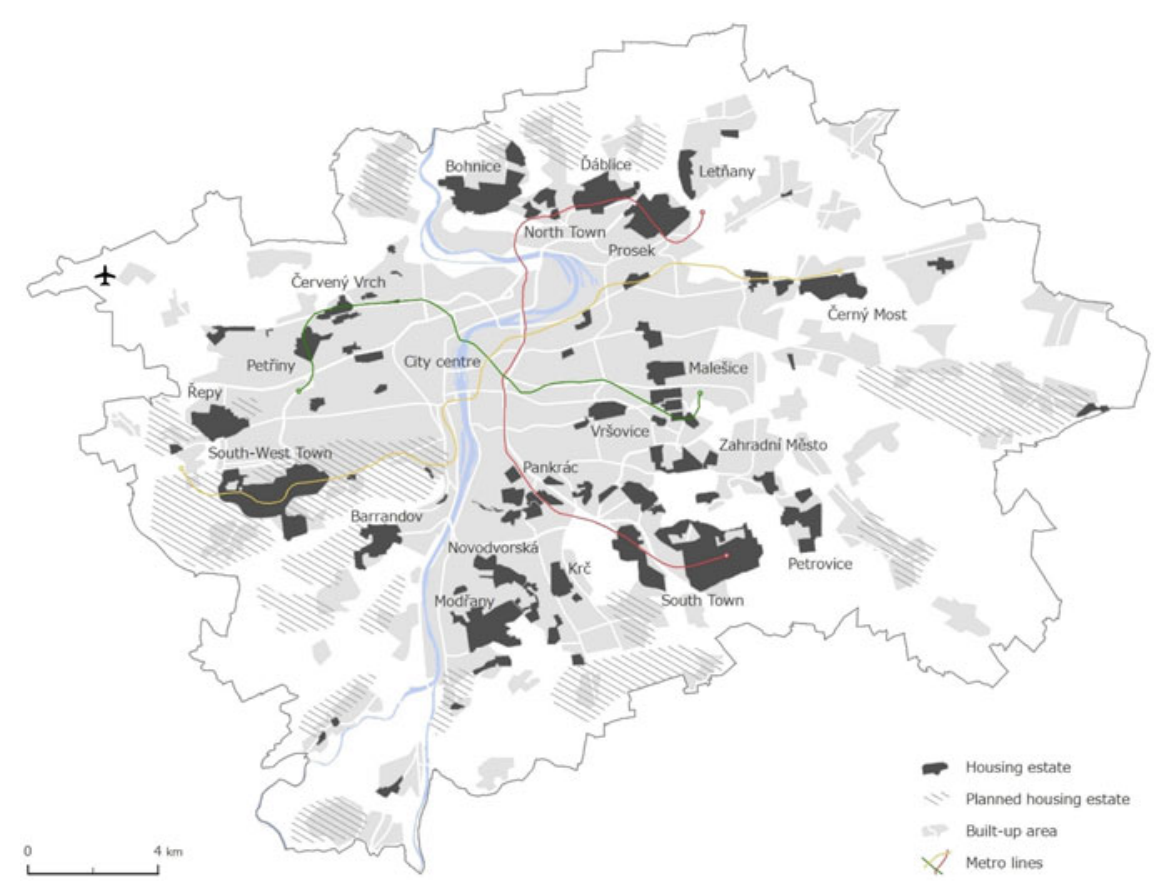

Fig. 15.1 Spatial pattern of housing estates in Prague. Source Jiří Nemeškal, 2017

Town (Severní Město), South Town (Jižni Město) and South-West Town (Jihozápadní Město). Metro lines serve these towns today, but in the early years, they suffered from a lack of social and cultural facilities and jobs. Housing estates erected on the outskirts then served as city dormitories with tens of thousands of people commuting every day to work, shopping and leisure activities in other parts of the city (Hrůza 1994; Maier et al. 1998). Several housing estates were never realised on the outskirts (see Fig. 15.1).

The proportion of the housing estate population has remained stable over the post-socialist period, ranging from 43 to $46 \%$ (Table 15.1). A large number of housing estates have experienced slow and gradual population loss via out-migration and a decrease in the average size of households. In other cases, positive net migration is a result of several new housing projects being built in these areas (Přidalová et al. 2015). In general, the number of inhabitants decreased by $20 \%$ in housing estates built prior to the 1970s. The percentage is even higher in the case of some older estates where the first residents are dying out (e.g. $40 \%$ for the Pankrác housing estate). Contrary to this development, estates built during the 1980s show a population increase connected to new housing construction in the form of infill development or larger complexes of new residential buildings (Fig. 15.2). 


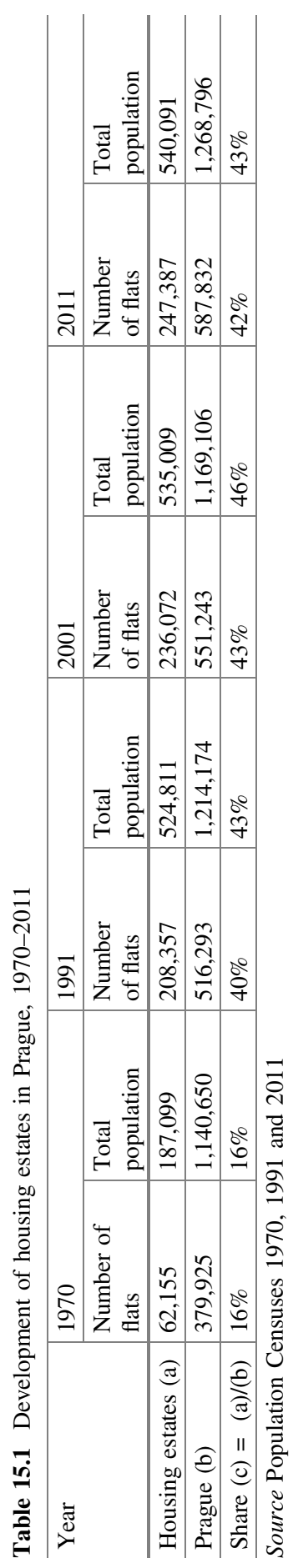



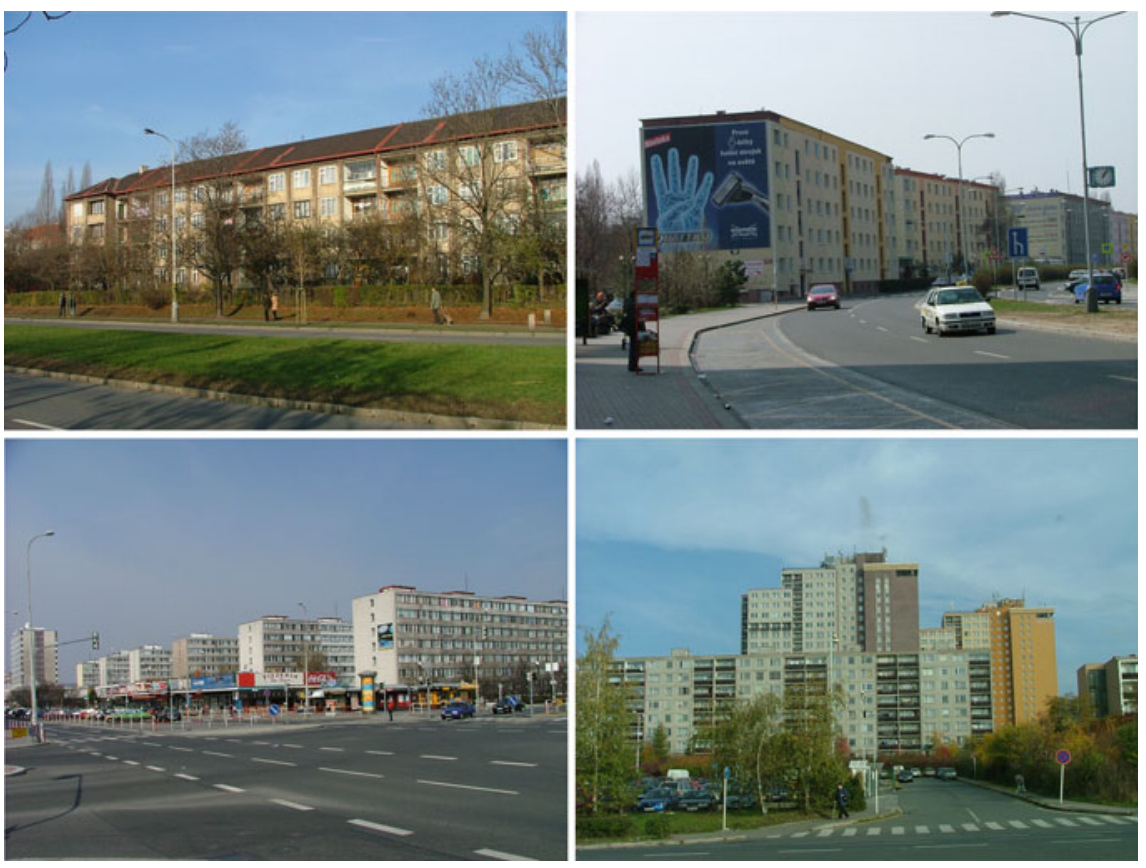

Fig. 15.2 Examples of housing estates in Prague: from top left, Solidarita (built during 19471949), Antala Staška (1954-1955), Pankrác (1964-1970) and South Town (1972-1992). Source Martin Ouředníček

\subsection{Development of Socio-Spatial Structure Within Socialist Housing Estates}

Socialist housing existed in Prague in four basic types of housing ownership: (i) state housing; (ii) socialist enterprise housing; (iii) cooperative housing and (iv) private housing (Musil 1987). State and enterprise construction was financed completely by public funds and mainly served employees of the socialist sector. Rent control and a policy of low rents were consistently applied (Musil 1987). Cooperative housing was based on a state grant and a low-rate loan together with families' private funds and was affordable for people who were able to contribute to the cost of house-building. All types of housing estates existed in the same place and there were no 'pure' cooperative or state estates, as there were in some other socialist countries (Musil 1987).

Allocation of individual apartments was fully in the hands of housing commissions (bytová komise), operated under national committees (Národní výbor), with building maintenance organised by District Housing Services Corporations (Obvodni podnik bytového hospodárství-OPBH). Through the national committees and other public institutions, the state regulated the use and construction of 
housing stock to limit the development of growing inequality in housing levels with regard to classes, social layers, social or demographic categories of the population, and also in respect to particular geographical areas (Musil 1987, p. 37). During the whole of the socialist era, the system of waiting lists (poradniky) for individual apartments was established as in many other socialist countries (compare Gentile and Sjöberg 2013). However, this system provided the opportunity for corruption (Musil 2002b; Lux and Sunega 2014). Among preferred groups with privileged positions were employees of industrial companies, working-class people, young households with children and households of employees in socially prominent organisations (e.g. police, army).

During the 1960s and 1970s, a significant proportion of new residents were former inhabitants of houses destroyed as a consequence of inner-city reconstruction programmes (Musil 2002b). In the 1970s, the strategy of Comprehensive Housing Construction compensated for the needs of Prague inhabitants in particular, but in the mid-1980s, a substantial part of the migration into the new residential areas seemed to consist of people moving from other parts of the Republic (Přidalová et al. 2015). This development was in accordance with the changing strategy of the Communist Party and the growing support of investment and relocation of the workforce to Prague. During this period, many inhabitants who moved within the administrative territory of Prague had previously lived in inner-city tenement houses and also in older housing estates (see Fig. 15.3).

Homogeneity of the housing estate population was primarily related to demographic status, as predominantly young families with children moved to newly built apartments (Matějů et al. 1979; Musil 1987; Temelová et al. 2011). However, regarding social status, newer estates were heterogeneous (Matějů et al. 1979; Musil 2006). In the first phase of housing estate construction, it was mostly working-class people who came to the newly built areas - more than $75 \%$ of them were young working-class households (Musil 1987). Consequently, an increasing diversity of housing, together with financial participation in cooperative housing, led to a more heterogeneous socio-economic structure in housing estates (Matějů et al. 1979; Musil 1987). Some flats in better quality estates were preferentially allocated to non-manual groups, with others, by contrast, allocated to manual workers (Linhart et al. 1977).

This heterogeneity was evident within individual housing estates, as well as between housing estates. First, a remarkably high social mix of various occupational groups was a characteristic of many housing estates which, in turn, were more socially mixed than the older parts of the city. For example, a university professor, industrial worker and bus driver might live in the same apartment building (Musil 1985). Second, we also observe significant differences in the social status of different housing estates. Although the housing estates showed average levels of both educational attainment and the proportion of employees in the secondary sector at the end of socialist period, a relatively high level of differentiation between individual housing estates was recorded (e.g. the proportion of university-educated ranged between 9.3 and $25.9 \%$ in 1991). Higher social status 


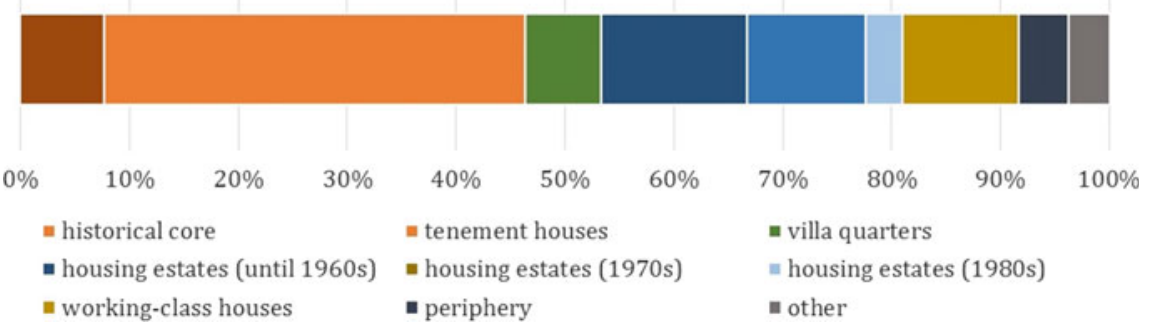

Fig. 15.3 Previous place of residence of new inhabitants of South Town and South-West Town, 1986-1988, N = 13470; Note tenement houses, villa quarters and estates from the 1960s are located within the inner-city and newer housing estates and working-class quarters are mainly in the outer city. Source IUD, 1989

was recorded in estates built up to the end of the 1960s (e.g. Pankrác, Petrriny) and also in the case of flats completed during the 1980s (e.g. Barrandov, Stodůlky).

On the other hand, lower socio-economic status as manifested both in low educational attainment and a high proportion of employees in the secondary sector of the economy was recorded in estates located in the eastern part of Prague (e.g. Černý Most, Kbely, Letňany). Apartments in these areas were preferentially allocated to factory employees. Therefore, we argue that spatial patterns of socio-economic structure perpetuated, to some extent, the pre-war status quo. Richer neighbourhoods were still located in western parts of the city, and poorer ones in the eastern parts of the city. This was partly due to the structure of local jobs and the proximity of industrial enterprises in the eastern part of the city, influenced by the prevailing westerly wind. Another reason was the area's flat terrain, which was more suitable for large-scale housing construction.

The role of ethnic groups was almost negligible in most housing estates during the socialist period. In general, the proportion of inhabitants with non-Czech ethnicity was low (only 4\%) and a majority of these were of Slovak ethnicity, i.e. citizens of Czechoslovakia. Selected estates accommodated higher numbers of Roma people (e.g. Repy, Stodůlky). However, their proportion in the population was generally lower than in inner-city neighbourhoods.

\subsection{Transformation Period: General Development and Socio-Spatial Differentiation}

The Velvet Revolution in November 1989 represents a 'break' point, after which fundamental changes took place, not only in politics and the economy but also in the spatial organisation of society and intra-urban spatial patterns (Musil 1993; Sýkora 1999; Hampl 2007). The first two decades of post-socialist urban development could be perceived as a period strongly influenced by transformation 
processes connected to transition from a socialist to a democratic society. These processes in Prague have been thoroughly described and evaluated (Eskinasi 1995; Sýkora 1999; Ouředníček and Temelová 2009), therefore we stress only those processes that directly influenced housing estate development in Prague. Among these, housing policy and dilution of public administration played crucial roles. Subsequent changes in ownership structure had a direct impact on the socio-spatial structures of the concerned housing estates.

All plans for new housing construction were halted almost immediately after the Velvet Revolution. The system of Comprehensive Housing Construction was terminated in 1993, and new housing construction was hindered by uncertainty about the restitution process, a real estate market that was developing slowly and the non-existence of financial tools to support housing. First attempts at humanising housing estates and their de-communisation in the form of simple changes were visible during early transformation period, particularly in streets, squares and institutional names (Kaltenberg-Kwiatkowska 2008). ${ }^{2}$ Housing estates were often negatively perceived, and were also presented in the media as communist symbols and so-called 'rabbit-hutches'; they were generally considered less attractive places to live. This all led to an uncertain future for housing estates, and a danger of stigmatisation and ghettoisation (Musil 2002a; Brade et al. 2009), which was strengthened by selective outflow of the well-off population during the first half of the 1990s (see below).

As highlighted by Musil (1993), housing policy in the early 1990s was very limited in that it did not aspire to provide state-controlled housing construction, social housing, or any reliance on large-state support for housing. This situation gradually changed during the mid-1990s with the establishment of a mortgage system, a new idea of building savings (stavebni spořeni), and restitution, which in combination helped to oil the wheels of the real estate market.

Decentralisation of self-government in Czechoslovakia was another important factor at the beginning of the 1990s. Prague itself changed from its former division of 10 administrative districts to 57 self-governed parts of the city. Several housing estate complexes on the outskirts became autonomous city parts, while older housing estates were incorporated into inner-city districts. In addition to the Prague City Assembly, each part of the city has its own assembly, council, mayor and independent budget, and also assumes some tasks in terms of state administration (Blažek et al. 1994). However, the scope of responsibilities of parts of the city is limited, with only poor control of urban planning and the economy of the city, which is in the hands of the Prague City Council. The role of self-government in city parts became especially important for housing policy. During the 1990s, it facilitated predominantly independent policies for the regeneration and privatisation of housing stock, which was transferred from the state to municipal ownership.

\footnotetext{
${ }^{2}$ As an example, the names of 12 stations on all three lines of the metro were changed.
} 
Privatisation of the formerly state and municipal housing stock was the core transformation process in housing estates. ${ }^{3}$ Each of Prague's 57 city parts devised its own privatisation policy because strategic decisions on the degree of privatisation were partly dependent on the political orientation of the ruling party. While more right-wing parties preferred privatisation of the entire housing stock, other city parts (e.g. К̌epy-social democratic) preferred to retain more housing units in municipal ownership (Musilová 2004). In the end, however, 90\% of former municipal housing stock was privatised (Burdová et al. 2012). Differences between city parts more or less levelled out, resulting in a proportion of non-privatised municipal houses of between 7 and $12 \%$, which is generally higher on housing estates than in other housing stock (Table 15.2).

Some city parts formulated their own regeneration strategies. At first, regeneration efforts focused on the built environment, namely on the revitalisation of housing stock. For example, Prague 11, comprising the South Town estate, commissioned an architectonic study to delimit the main principles of regeneration and guide particular renovation projects. Later, the focus also shifted more intensively to the revitalisation of public spaces. Among other initiatives, a pilot project based on participative planning was carried out in part of the Černý Most estate. At the same time, there was a larger impetus to promote community and cultural life, for example, Prague 14 (which includes the Černý Most and Hloubětín estates) created the organisation 'Praha 14 cultural' for these purposes. Last, there are no plans for the demolition of pre-fab houses; on the contrary, housing in these estates is in high demand, and new residential areas are quickly developing there.

More importantly, however, several state programmes specifically aimed at regeneration of housing estates were introduced at the dawn of twenty-first century. Most of the subsidy programmes coordinated by the Ministry of Regional Development and the Ministry of Environment focus on improving the state of buildings from a technical point of view, ${ }^{4}$ although some also cover the revitalisation of public spaces within housing estates (e.g. European Structural Funds, IPRM programme) (Šimáček et al. 2015). Thus, the remodelling of apartments, regeneration of panel houses, and revitalisation of public areas constituted the most common interventions within Czech housing estates (Šimáček et al. 2015). Enhancement of energy efficiency is the main motivation for the renovation of housing stock (Němec 2011). Most renovation activities are small-scale and are organised by individual owners and associations (private, cooperative and public).

According to analysis by the Institute of Planning and Development, most of the older housing estates in Prague have been completely regenerated (Ď́alice $68 \%$ of apartment buildings, Malešice 68\%, and Bohnice 67\%), while in younger estates sometimes fewer than $20 \%$ of apartment buildings have seen full reconstruction

\footnotetext{
${ }^{3}$ Today, some city authorities often sell apartments in housing estates to sitting tenants in Prague for one-third of the commercial value. During the 1990s, the prices were much lower, with flats being sold to tenants for about 2,000 CZK per m² (Kostelecký 2000, p. 188).

${ }^{4}$ Examples of building improvements include repairs of defects in panel buildings (1998-2005), new panel installation (2002-2015), and a new Green Savings Programme (2009-2020).
} 


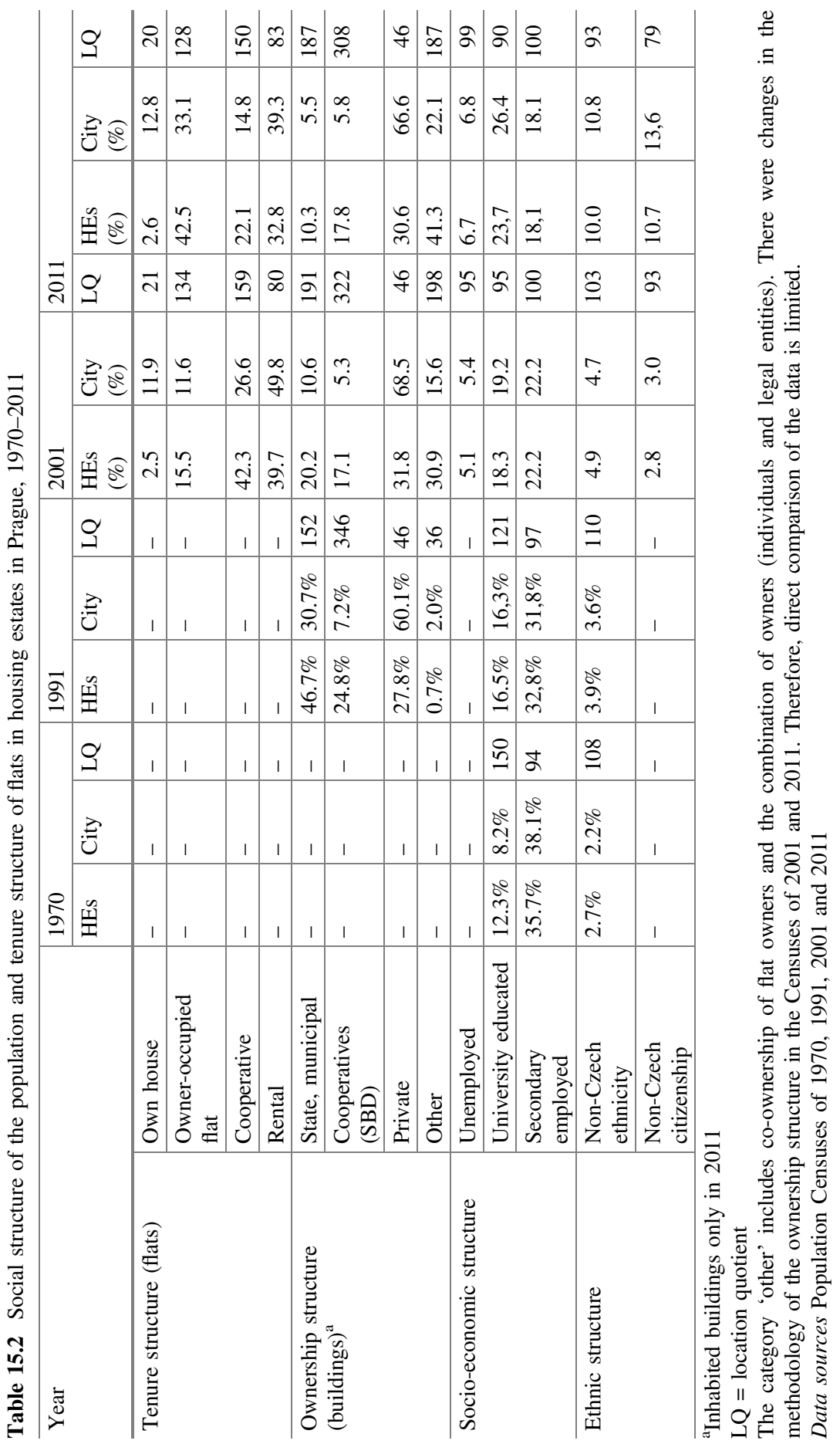


(Němec 2011). Because the sum of the average proportions of completely regenerated (42\%) and partly regenerated (48\%) apartment buildings is high, we might contend that in general they are well maintained by their owners. In this context, Němec (2011) argues that cooperative ownership results in the highest proportion of reconstructed dwellings. This could be explained by the greater ability of larger cooperatives to gain professional help in the renovation process (Karasek and Ubralova 2012).

Development of tenure structure in housing estates reflects the development of the housing market in Prague as a whole. We observe an increase in the number of owner-occupied flats connected with the transformation of housing cooperatives (bytové družstvo) into associations of owners (společenství vlastnikü) and with the large-scale privatisation of the housing stock from the public (state or municipal) into private hands (Table 15.2). Therefore, the proportion of flats that are rented has seen a slight decrease, and the composition of landlords has changed (from state and city into private flat owners). Former tenants, thus, remained in their dwellings, and as homeowners they started to invest in modernisation of their homes, thereby maintaining the attractiveness of estates. Such behaviour helped to maintain a relatively favourable social composition of the population in housing estates and, to some extent, the social mix as well, at least for a few decades. Indeed, housing estates in which the flats are occupied by their owners show a generally higher level of socio-economic status of their populations (compared to housing estates with higher proportions of rented housing).

The proportion of public housing is relatively low in Prague. According to the most recent census data from 2011, only 5.5\% of all inhabited houses were owned by the municipality or by the state in Prague, with $10.3 \%$ on housing estates (Table 15.2). It is interesting to note that more than 25 years after the fall of the communist regime, there is no legislation defining social housing (sociální bydleni) at the national level in Czechia. The policy of social housing is, therefore, in the hands of municipalities (or municipal districts), which approach it rather differently, with social allowances being the main tool to support low-income groups in paying housing rent.

In general, with the higher proportion of flats in public ownership, the socio-economic status of housing estate populations tends to be lower (i.e. a higher proportion of unemployed and lower proportion of university-educated residents). Indeed, in some units with higher concentrations of municipal housing, we observe a relatively low level of socio-economic status of the populations (Černý Most and Lehovec estates). In other units, however, socio-economic status is average compared with the general population (or even above-average). Despite a higher share of municipal housing stock in housing estates compared to the average for Prague, only part of it is used for social housing. Other flats are inhabited by tenants who have been living in their flats ever since the socialist period or are leased out by city authorities for market rent.

Considering the socio-economic patterns of the transformation period, analysis shows a gradual process of social degradation of housing estates as expressed by the educational structure of the population in comparison with development of the 
city. Dynamics of the increase in educational attainment show that it is lower than the city average, which results in a lower proportion of university-educated people. However, the proportion of unemployed, and employed in the secondary sector of the economy, is slightly less than the city average (Table 15.2).

Moreover, we observe different dynamics in variations in educational and employment structures. First, housing estates already experienced a sharp decrease in the proportion of secondary-sector employed residents during the 1990s; this change was tied to the transformation of the city's economy together with rapid deindustrialisation. Second, in the case of educational structure, the increase in the level of education was relatively slow in the 1990s compared with the period between 2001 and 2011 (in housing estates as well as in the city as a whole). In some housing estates, we even observe a slight decrease in the proportion of university-educated people (e.g. Modřany, Hostivař-Košík, Řepy and LibušPísnice). Although part of this change can be ascribed to the 'nest-emptying' process, some better-off people who could afford to move from housing estates gradually out-migrated from these areas during this period. Suburbanisation was one of the new processes that supported this out-migration (Ouředníček 2007).

Faster growth in educational attainment after 2001 was caused by greater availability of university education (increasing numbers of students at public and private universities), the age structure of Prague's population in which there was a high proportion of inhabitants born in the 1970s who had just finished their university studies, and the general attractiveness of Prague for young, educated people from other parts of the country. Nonetheless, growth in educational attainment was lower in housing estates than in other parts of the metropolitan region.

The process of relatively slow degradation, however, is not exclusively connected with the post-socialist transformation. It is possible to see the worsening of the educational structure even before the end of socialism. Even in 1991, the zone of housing estates showed 'only' average educational attainment compared with the rest of the city (Table 15.2). The rate of decrease of educational attainment is relatively stable over time. Besides other factors such as the out-migration of the better-off to other parts of the metropolitan region, it can be ascribed to the natural ageing of the local population.

When analysing spatial patterns, we observe a relative inertia following the end of the socialist period. Two groups of housing estates show worse educational and economic structure of the population. These estates, first, are located on the outskirts of the city, some with poor transportation accessibility, built either in the 1970s (Modřany, Lehovec and South Town) or in the 1980s (Černý Most and Horní Měcholupy-Petrovice). Second, populations with lower social status live in older housing estates with a high proportion of senior citizens (Zahradní Město, Malešice and Novodvorská). On the other hand, housing estates with excellent accessibility and location within the city remain an attractive residential choice for the better-off population and retain their higher social status despite a higher proportion of senior citizens (Petřiny, Červený Vrch, Pankrác and Solidarita). Similarly, estates with new housing construction attract economically stronger populations (e.g. Barrandov and Hostivař-Košík). 
The proportion of the foreign-born population is relatively low in housing estates compared to the city average. There are also considerable differences in the structure of the foreign population according to the country of origin. While better-off foreigners from the Western world tend to seek flats in the city centre and suburbs, comparatively cheaper housing estates attract post-Soviet and Asian foreigners (Přidalová and Ouředníček 2017). Ukrainians, Russians and Vietnamese are the most common ethnic groups. Interestingly, foreign nationals tend to create ethnic enclaves in some housing estates. For example, a Vietnamese minority is concentrated in Libuš-Písnice nearby the Vietnamese market SAPA, and Russian-speaking foreigners are over-represented in the South-West Town (Přidalová 2017).

\subsection{Post-transformation Development}

As we previously argued elsewhere (Ouředníček and Pospíšilová 2016), in Czechia the era of large transformation processes and systematic changes in the legislative, administrative, and other norms formed under the socialist regime is now at an end. The transformation processes - including restitution, privatisation, rent regulation, administrative, and legislative changes - can also be regarded as complete in Prague. By the end of 2012, rent regulation had ceased, and privatisation had finished in most city parts by around 2015. Post-transformation development in housing estates cannot be described using census data (the last census took place in 2011). However, we aim to illustrate the contemporary position of housing estates in Prague's residential environment using spatial patterns of new housing construction and house prices, both of which significantly influence the socio-economic status of the populations of housing estates.

The location of new residential construction is one of the most important factors in the socio-spatial differentiation of Prague. It might be surprising in some respects that after the Velvet Revolution many areas of new residential development were located in neighbourhoods that had previously been socially poor, in formerly neglected suburbs (Ouředníček 2007; Špačková and Ouředníček 2012) and inner-city working-class neighbourhoods (Ilík and Ouředníček 2007; Temelová 2007; Špačková and Sýkora 2017). A similar development was seen on housing estates (Ouředníček 2016; Špačková et al. 2016), where several examples of new housing construction were realised on the edges of estates (Fig. 15.4). Developers have been attracted to these parts of the city because housing estates provided building plots, coming with technical and social infrastructure and good transportation to the city centre. For example, $43 \%$ (48 out of all 111 residential projects) of new housing development were located within housing estate zones in 2014 (Němec 2014). Because the prices of apartments in pre-fab panel houses and newly built apartments differ considerably, a specific type of micro-spatial polarisation of new housing occurred. It is an open question, however, whether this supports more of a social mix in housing estates, or social polarisation or micro-segregation of new and old residents. 
Housing prices characterise quite well the position of housing estates within the real estate market in Prague, as well as the relative socio-economic status of housing estates. Wagner (2017) documents that apartments in housing estates today occupy the cheapest segment of Prague's real estate market. The same finding was described at the micro level of individual neighbourhoods (Ilík and Ouředníček 2007; Wagner 2017). The largest of Prague's housing estates, South Town, is now the cheapest place to live in Prague (when we exclude dormitories and other non-standard housing). However, as we argue elsewhere (Ouředníček 2016; Špačková et al. 2016), in relation to other housing estates within Czechia but also in relation to suburban housing, even the flats in the cheapest housing estates in Prague are still very expensive.

Prague's housing market extends far beyond the administrative boundary of the city and covers a large part of Central Bohemia. Commuting is still an important part of daily mobility, with long commuting distances extending beyond the boundaries of Central Bohemia. Prices of housing estates in smaller towns within the Prague metropolitan region are much lower. This is one of the factors actively protecting social downgrading of housing stock in Prague and subsequent large-scale deprivation in housing estates. This is also why it is hard to find deprived parts of Prague's housing estates (Kostelecký et al. 2012; Ouředníček 2016; Špačková et al. 2016). On the other hand, there are strong social problems in other parts of Czechia, and areas of social exclusion are often located within housing estates (Temelová et al. 2011; Čada et al. 2015).

\subsection{Conclusion and Discussion of Future Developments}

While the transformation period was typified by top-down development, contemporary changes in the housing estate environment are more spontaneous and market-driven. In other words, during the transformation period programmes aimed towards privatisation (small properties and housing), and the regeneration of houses and public places were managed under state and municipal policies. Rather than large regeneration projects, nowadays commercial forces and the free market influence the rapid development of residential and commercial areas within housing estates in Prague. Generally, policies aimed at regeneration are not seen as being among the top priorities of the city as a whole or in any of its parts. This was confirmed by Kostelecký et al. (2012) who analysed the results of 23 in-depth interviews with local politicians and officers. We argue that this situation is partially influenced by considerably lower (and decreasing) levels of socio-spatial disparity within the city and also by the belief of local actors that social and physical conditions in Prague will change for the better without significant efforts by anyone in the public sphere. As a result, no specific policy for housing estates is now articulated at the level of Prague. The new Metropolitan Plan of Prague concentrates on the protection and liveability of green public spaces (parks), but no other topics for housing estates are mentioned. On the other hand, the new strategic plan 


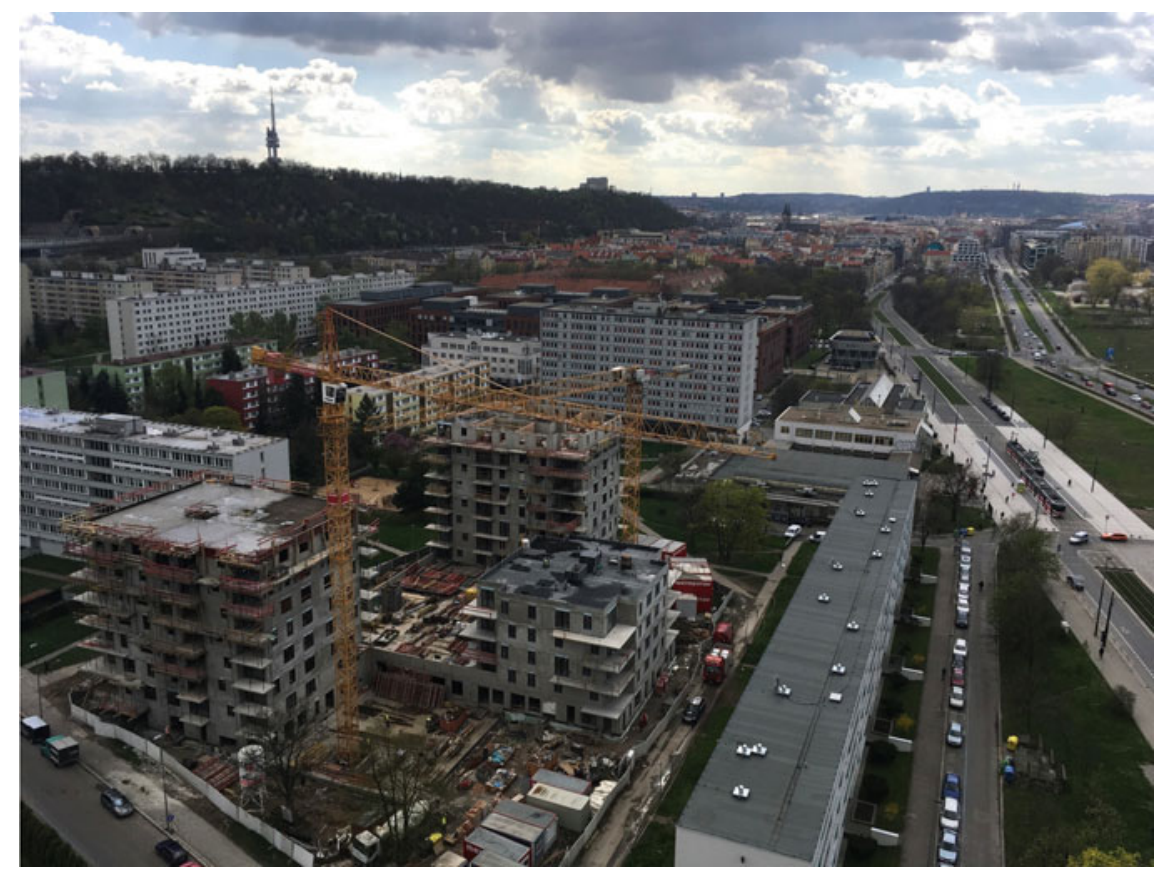

Fig. 15.4 Karlín Park, a new residential project on the site of a former kindergarten, is located in the core of the Invalidovna housing estate. Source Martin Ouředníček

contains several suggestions of activities to improve the quality of life specifically aimed at housing estate neighbourhoods.

Today, most of the housing estates in Prague can be evaluated as non-problematic residential areas. They are very stable parts of the metropolis, with the lowest fluctuation of people among all other types of residential areas (Přidalová and Ouředníček 2017), with a growing diversification of functional use, different types of housing and socio-economic differentiation. Housing estates have very low segregation tendencies (Ouředníček et al. 2016), although there are a number of enclaves of foreigners from the post-Soviet regions and Asia. Many estates are preferred for new investment and are in-demand places to live (Temelová et al. 2011). Although several localities with deteriorating social structure can be found in Prague, these are more the outcome of specific policies (e.g. the intentional movement of specific groups into these localities) (Matoušek and Seidlová 2010) than a sign of change for housing estates. The reasons for this can be seen in housing policies on the one hand (long-term rent regulation, large-scale privatisation, high share of flats in private hands, programmes for housing estate regeneration) and a prevailing reluctance to change the typical place of residence for the Czech population on the other (Lux et al. 2005).

Apart from residential functions, housing estates accommodate new services, offices and entertainment. Moreover, these functions have also brought a number of 
jobs with them, and selected housing estates have appeared as new centres of commuting themselves. Today, shopping malls such as Centrum Černý Most, Centrum Chodov, Metropole Zličín and others are retail centres of regional importance.

As discussed in the introduction, housing estates can be perceived as a symbol of the socialist era. Nevertheless, they are also living environments in which many Prague citizens grew up. Local playgrounds, schools, balconies, lifts and carpet beating stands are important places of memory and sentiment for all those people who have ever lived in housing estates, for whom the living environment there is perceived to be acceptable for starter apartments for their children. If we also take non-residents into consideration-other users of housing estate services, workplaces and entertainment - housing estates will increasingly become integral parts of the city as a whole, partly as an outcome of polycentric development and decentralisation policies. It seems that over the next few decades, the housing estates of Prague will constitute just one of the many historical layers of the housing stock of the city, just as houses from the Middle Ages and the industrial era are currently stable parts of the urban environment.

Acknowledgements This chapter was supported by the Czech Science Foundation grant number GA18-14510S, 'Contemporary changes of social environment within the Czech suburbs'.

\section{References}

Barvíková J (2010) Jak se žije na Jižním Městě z pohledu "Husákových dětí" (What's the Life Like in Housing Estate Jižní Město from the "Husák's children” Generation Point of View). Sociální studia 7(3):59-78

Blažek J, Hampl M, Sýkora L (1994) Administrative system and development of Prague. In: Barlow M, Dostál P, Hampl M (eds) Development and administration of Prague. Universiteit van Amsterdam, Amsterdam, pp 73-87

Borovička B, Hrůza J (1983) Praha. 1000 let stavby města. Panorama, Prague

Brade I, Herfert G, Wiest K (2009) Recent trends and future prospects of socio-spatial differentiation in urban regions of Central and Eastern Europe: a lull before the storm? Cities 26 (5):233-244. https://doi.org/10.1016/j.cities.2009.05.001

Burdová B, Chlupová D, Polešáková M, Rohrerová L (2012) Výsledky dotazníkové akce o změnách v obecním bytovém fondu ve vybraných městech $(2010,2011)$

Čada K, Büchlerová D, Korecká Z, Samec T, Ouředníček M, Kopecká Z (2015) Analýza sociálně vyloučených lokalit v ČR. GAC, Ministry of Labour and Social Affairs, Prague

Eskinasi M (1995) Changing housing policy and its consequences: the Prague case. Housing Stud 10(4):533-548. https://doi.org/10.1080/02673039508720836

Gentile M, Sjöberg Ö (2013) Housing allocation under socialism: the Soviet case revisited. Post-Soviet Affairs 29(2):173-195. https://doi.org/10.1080/1060586X.2013.782685

Hampl M (2007) Regionální diferenciace současného socioekonomického vývoje v České republice. Sociologický časopis/Czech Soc Rev 43(5):889-910

Hampl M, Kühnl K (1993) Migratory trends in former Czechoslovakia. Acta Universitatis Carolinae-Geographica 28(1):53-71

Hrůza J (1989) Město Praha. Odeon, Prague 
Hrůza J (1994) Historical development of Prague. In: Barlow M, Dostál P, Hampl M (eds) Development and administration of Prague. Universiteit van Amsterdam, Amsterdam, pp $15-28$

Ilík J, Ouředníček M (2007) Karlín a jeho proměny v souvislostech postsocialistické transformace Prahy. Geografie 112(3):292-314

Kaltenberg-Kwiatkowska E (2008) Street names between sign and symbol. The case of Poland and the Czech Republic. In: Strubelt W, Gorzelak G (eds) City and region. Papers in Honour of Jiří Musil. Budrich UniPress, Opladen, Farmington Hills, pp 157-192

Karasek J, Ubralova E (2012) Czech Republic: energy efficiency increasing in the housing stock. In: Nieboer N, Tsenkova S, Gruis V, van Hal A (eds) Energy efficiency in housing management. Policies and Practices in Eleven Countries. Routledge, London, pp 176-194

Kohout J, Vančura J (1986) Praha 19. a 20. století. Technické proměny. SNTL, Prague

Kostelecký T (2000) Housing and its influence on the development of social inequalities in the post-communist Czech Republic. Czech Sociol Rev 8(2):177-193

Kostelecký T, Patočková V, Illner M (2012) Problémové rezidenční čtvrti a politiky k jejich regeneraci v postsocialistickém městě—studie Prahy. Sociologický časopis/Czech Sociol Rev 48(1):39-63

Linhart J, Rak V, Voženílek J (1977) Sociální aspekty ekologické zónace hlavního města Prahy. Sociologický časopis/Czech Sociol Rev 13(1):94-115

Lux M, Sunega P (2014) Public housing in the post-socialist states of Central and Eastern Europe: decline and an open future. Housing Stud 29(4):501-519. https://doi.org/10.1080/02673037. 2013.875986

Lux M, Sunega P, Kostelecký T, Čermák D, Montag J (2005) Standardy bydlení 2004/05. Financování bydlení a regenerace sídlišt'. Sociological Institute, Prague

Maier K (2003) Sídliště: problém a multikriteriální analýza jako součást př́ípravy k jeho řešení. Sociologický časopis/Czech Sociol Rev 39(5):653-666

Maier K, Hexner M, Kibic K (1998) Urban development of Prague: history and present issues. Czech Technical University in Prague, Prague

Matějů P (1977) Sociologické aspekty vývoje bydlení v Praze. Sociologický časopis/Czech Sociol Rev 13(1):39-58

Matějů P (1980) Vývoj sociálně prostorové struktury Prahy v letech 1930-1970 ve světle faktorové analýzy. Sociologický časopis/Czech Sociol Rev 16(6):572-591

Matějů P, Večerník J, Jeřábek H (1979) Social structure, spatial structure and problems of urban research: the example of Prague. Int J Urban Reg Res 3(1-3):181-202. https://doi.org/10.1111/ j.1468-2427.1979.tb00785.x

Matoušek R, Seidlová M (2010) Residenční segregace v Česku: Praha-Černý Most. In: Sýkora L (ed) Rezidenční segregace. Charles University in Prague and Ministry of Regional Development, Prague, pp 112-116

Musil J (1985) Lidé a sídliště. Svoboda, Prague

Musil J (1987) Housing policy and the sociospatial structure of cities in a socialist country: the example of Prague. Int J Urban Reg Res 11(1):27-36. https://doi.org/10.1111/j.1468-2427. 1987.tb00033.x

Musil J (1993) Changing urban systems in post-communist societies in Central Europe: analysis and prediction. Urban Stud 30(6):899-905

Musil J (2002a) Co se děje s českými městy dnes. In: Horská P, Maur E, Musil J (eds) Zrod velkoměsta. Urbanizace českých zemí a Evropa, Paseka, Prague, Litomyšl, pp 298-331

Musil J (2002b) Urbanizace českých zemí a socialismus. In: Horská P, Maur E, Musil J (eds) Zrod velkoměsta. Urbanizace českých zemí a Evropa. Paseka, Prague, Litomyšl, pp 237-297

Musil J (2005a) City development in Central and Eastern Europe before 1990: Historical context and socialist legacies. In: Hamilton FEI, Andrews KD, Pichler-Milanović N (eds) Transformation of cities in Central and Eastern Europe: towards globalization. United Nations University Press, Tokyo-New York, pp 22-43 
Musil J (2005b) Prague returns to Europe. In: Hamilton FEI, Andrews KD, Pichler-Milanović N (eds) Transformation of cities in Central and Eastern Europe: towards globalization. United Nations University Press, Tokyo-New York, pp 281-317

Musil J (2006) Prague, present meets past. Int Rev Sociol 16(2):243-272. https://doi.org/10.1080/ 03906700600708840

Musilová M (2004) Regenerace panelových sídlišt’: př́iklad pražských sídlišt' Řepy, Letňany a Opatov. Charles University in Prague, Faculty of Science, Prague

Němec M (2011) Analýza stavu oprav a rekonstrukcí bytových domů alokovaných ve velkých sídlištních celcích hl. m. Prahy. Institute for Planning and Development, Prague

Němec M (2014) Domovní a bytový fond $\mathrm{v}$ detailu pražských městských částí z pohledu statistických ukazatelů. Institute for Planning and Development, Prague

Novotná B (2010) Panelák jako symbol a místo paměti Sociální studia 7(3):127-131

Ouředníček M (2007) Differential suburban development in the Prague urban region. Geografiska Annaler: Human Geography 89B(2):111-125

Ouředníček M (2016) The relevance of "Western" theoretical concepts for investigations of the margins of post-socialist cities: the case of Prague. Eurasian Geogr Econ 57(4-5):545-564. https://doi.org/10.1080/15387216.2016.1256786

Ouředníček M, Pospíšilová L (2016) Editorial: urban dynamics and neighbourhood change in cities after transition. Sociologický časopis/Czech Sociol Rev 52(6):787-794

Ouředníček M, Pospíšilová L, Špačková P, Kopecká Z, Novák J (2016) The velvet and mild: socio-spatial differentiation in Prague after transition. In: Tammaru T, Marcińczak S, van Ham M, Musterd S (eds) Socio-economic segregation in European capital cities: east meets west. Routledge, Abingdon, New York, pp 261-286

Ouředníček M, Temelová J (2009) Twenty years after socialism: the transformation of Prague's inner structure. Studia Universitatis Babes-Bolyai, Sociologia 54(1):9-30

Přidalová I (2017) Cizinci a lokální sociální prostředí: př́ípadová studie Hůrka. In: Ouředníček M, Jíchová J (eds) Sociální prostředí Prahy: město na prahu 21. století. Academia, Prague, pp 120 149

Přidalová I, Ouředníček M (2017) Role zahraniční migrace v měnící se sociálně-prostorové diferenciaci Prahy. Sociologický časopis/Czech Sociol Rev 53(5):659-692. https://doi.org/10. 13060/00380288.2017.53.5.360

Přidalová I, Ouředníček M, Nemeškal J (2015) Historical aspects of migration in Prague. Specialized map. Charles University in Prague, Faculty of Science, Department of Social Geography and Regional Development, Prague

Skřivánková L, Švácha R, Novotná E, Jirkalová K (2017) The Paneláks: twenty-five housing estates in the Czech Republic. The Museum of Decorative Arts in Prague, Prague

Steinführer A (2003) Sociálně prostorové struktury mezi setrvalostí a změnou. Historický a současný pohled na Brno. Sociologický časopis/Czech Sociol Rev 39(2):169-192

Sýkora L (1999) Processes of socio-spatial differentiation in post-communist Prague. Housing Stud 14(5):679-701. https://doi.org/10.1080/02673039982678

Šimáček P, Szczyrba Z, Andráško I, Kunc J (2015) Twenty-five years of humanising post-socialist housing estates: from quantitative needs to qualitative requirements. Geographica Polonica 88 (4):649-668. https://doi.org/10.7163/GPol.0038

Špaček O (2012) Česká panelová sídliště: faktory stability a budoucího vývoje. Sociologický časopis/Czech Sociol Rev 48(5):965-988

Špačková P, Ouředníček M (2012) Spinning the Web: New Social Contacts of Prague's Suburbanites. Cities 29(5):341-349

Špačková P, Pospíšilová L (2017) Diferenciace českých panelových sídlišt' z hlediska vzdělanosti jejich obyvatel: stav a dlouhodobý vývoj. Historická geografie 43(2):171-190

Špačková P, Pospíšilová L, Ouředníček M (2016) The long-term development of socio-spatial differentiation in socialist and post-socialist Prague. Sociologický časopis/Czech Sociol Rev 52 (6):821-860. https://doi.org/10.13060/00380288.2016.52.6.288

Špačková P, Sýkora J (2017) Kontrasty sociálních světů v dolních Holešovicích. In: Jíchová J (ed) Sociální prostředí Prahy: město na prahu 21. století. Academia, Prague, pp 92-119 
Zadražilová L (2013) Když se utopie stane skutečností. Panelová sídliště v Československu 19531989. Arbor Vitae, The Museum of Decorative Arts in Prague, Prague

Zarecor KE (2011) Manufacturing a socialist modernity: housing in Czechoslovakia, 1945-1960. University of Pittsburgh Press, Pittsburgh

Temelová J (2007) Flagship developments and the physical upgrading of post-socialist inner city: the golden angel project in Prague. Geografiska Annaler: Human Geogr 89B(2):169-181

Temelová J, Novák J, Ouředníček M, Puldová P (2011) Housing Estates after socialism: various trajectories and inner differentiation. Urban Stud 48(9):1811-1834. https://doi.org/10.1177/ 0042098010379279

Temelová J, Slezáková A (2014) The changing environment and neighbourhood satisfaction in socialist high-rise panel housing estates: the time-comparative perceptions of elderly residents in Prague. Cities 37:82-91. https://doi.org/10.1016/j.cities.2013.12.002

Wagner M (2017) Ceny bydlení v Praze. Charles University, Faculty of Science, Prague

Votrubec C (1965) Praha-zeměpis velkoměsta. SPN, Prague

Open Access This chapter is licensed under the terms of the Creative Commons Attribution 4.0 International License (http://creativecommons.org/licenses/by/4.0/), which permits use, sharing, adaptation, distribution and reproduction in any medium or format, as long as you give appropriate credit to the original author(s) and the source, provide a link to the Creative Commons license and indicate if changes were made.

The images or other third party material in this chapter are included in the chapter's Creative Commons license, unless indicated otherwise in a credit line to the material. If material is not included in the chapter's Creative Commons license and your intended use is not permitted by statutory regulation or exceeds the permitted use, you will need to obtain permission directly from the copyright holder. 